\title{
WATERMARKING CITRA DIGITAL BERWARNA MENGGUNAKAN STATIONARY WAVELET TRANSFORM (SWT)
}

\author{
Fitriyani Umar ${ }^{1}$, Herdianti Darwis ${ }^{2}$ \\ 1fitriyani.umar@umi.ac.id, herdianti.darwis@umi.ac.id² \\ 1,2Universitas Muslim Indonesia
}

\begin{abstract}
Abstrak
Watermarking citra digital banyak digunakan dan diteliti untuk masalah kepemilikan (ownership), proteksi, autentikasi dan identifikasi pemilik data digital. Skema watermarking yang baik yaitu memenuhi kriteria imperceptibility, robustness dan capacity. Penelitian ini bertujuan untuk membuat skema watermarking yang memiliki imperceptibility yang baik dan tahan (robust) terhadap serangan menggunakan Stationary Wavelet Transform (SWT). Pengujian dilakukan pada dua level transformasi dengan serangan Salt and Pepper, Speckle, Gaussian Noise, Blur, kompresi dan rotasi untuk robustness. Metode yang digunakan menghasilkan impercebtility yang baik dengan nilai PSNR di atas $70 \mathrm{~dB}$ pada level 1 dan di atas $40 \mathrm{~dB}$ pada level 2. Adapun pengujian robustness juga menunjukkan hasil yang sangat baik dengan nilai Normalized Correction di atas 0.9466 di level 1 dan di atas 0.9714 pada level 2. Ini juga menunjukkan bahwa dari segi imperceptibility, nilai PSNR pada level 1 lebih baik dibandingkan pada level 2. Dari segi robustness, level 2 lebih baik daripada level 1.
\end{abstract} Kata kunci: Stationary Wavelet Transform (SWT), imperceptibilty, robustness, PSNR, Normalized Correction.

\begin{abstract}
Digital Image watermarking is widely used and studied for ownership identification, data protection, and authentication. A good watermarking scheme should achieve the watermarking requirements such as imperceptibility, robustness and capacity. This research aims to make robust and imperceptible watermarking by using Stationary Wavelet Transform. The test is done on two levels of transformation and attacked by Salt and Pepper, Speckle, Gaussian Noise, Blur, Compression and Rotation. The results show that method used in this research gives good impercebtility with PSNR value larger than $70 \mathrm{~dB}$ on level 1 and larger than $40 \mathrm{~dB}$ on level 1 . The Robustness test also shows a good result where Normalized Correction value larger 0.9466 on level 1 and larger than 0.9714 on level 2. This also shows that for imperceptibilty, level 1 of transformation gives higher results than in level 2 of transformation, while for robustness, level 2 achieves better value than level 1.
\end{abstract}

Key words: Stationary Wavelet Transform (SWT), imperceptibilty, robustness, PSNR, Normalized Correction.

\section{Pendahuluan}

Penggunaan internet dan jaringan komputer yang semakin meningkat dari hari ke hari mengakibatkan distribusi citra digital juga semakin mudah. Citra digital merupakan gambar dua dimensi yang telah didiskretisasi sehingga dapat ditampilkan di komputer. Media ini banyak digunakan untuk keperluan penyajian informasi grafis atau visualisasi dan promosi produk. Keunggulannya yang bersifat mudah untuk digandakan dan dimanipulasi juga sekaligus dapat menjadi ancaman jika dilakukan oleh orang yang tidak bertanggung jawab. Misalnya, seseorang mengubah sebagian informasi citra suatu produk yang didapatnya dari internet kemudian menyebarkannya untuk kepentingan tertentu tanpa izin dari pemilik yang sah. Oleh karena itu,diperlukan adanya upaya untuk menyisipkan informasi ke dalam citra digital sebagai tanda kepemilikan yang sah atau keaslian dari suatu media digital.

Teknik watermarking hadir sebagai salah satu cara untuk menyelesaikan masalah ini. Teknik ini merupakan metode penyembunyian informasi ke dalam data digital (disebut dengan host) dimana informasi ini dapat dikembalikan menurut kebutuhan. Informasi yang disembunyikan dapat berupa gambar (citra) yang menunjukkan identitas kepemilikan yang disebut dengan watermark. Sampai saat ini, teknik watermarking masih menjadi topik yang menarik. Ini banyak digunakan dan diteliti untuk masalah kepemilikan (ownership), proteksi, autentikasi dan identifikasi pemilik data digital[1]-[3].

Secara tradisional, watermark yang disisipkan dapat terlihat oleh mata manusia (visible watermark). Namun, hal ini membuat media tempat disisipkannya (data host) watermark mengalami kerusakan atau distorsi dan mengurangi kualitas citranya. Secara umum, kriteria utama yang harus 
ILKOM Jurnal Ilmiah Volume 11 Nomor 1 April 2019

Terakreditasi peringkat 3 SK. No. 28/E/KPT/2019

dipenuhi untuk menunjang skema watermarking yang baik, yaitu kriteria imperceptibility, robustness dan capacity[4]. Imperceptibility merupakan kriteria yang menunjukkan bahwa informasi yang disisipkan tidak merusak kualitas citra host. Robustness menunjukkan kemampuan watermark bertahan jika diberi serangan terhadap pemrosesan citra digital ataupun upaya menghapus watermark di dalamnya. Adapun capacity adalah besarnya data yang dapat disisipkan ke dalam host.

Penelitian ini bertujuan untuk membuat skema watermarking yang tahan (robust) terhadap serangan dan memiliki imperceptibility yang baik dengan pemanfaatan domain transform menggunakan Stationary Wavelet Transform (SWT). SWT merupakan perkembangan dari DWT yang menghapus proses downsampling yang mengakibatkan tidak terjadinya pergeseran invarian saat terjadi transformasi. Penelitian yang dilakukan oleh N. Choubey dan M. K. Pandey [5] juga memakai SWT namun untuk citra greyscale dan watermark disisipkan pada subband dengan frekuensi rendah melalui nilai singular. Penyisipan citra dilakukan di frekuensi rendah karena menghasilkan citra yang mirip dengan aslinya.

Adapun pada penelitian ini, citra watermark dan host yang digunakan adalah citra berwarna (RGB) yang disisipkan pada frekuensi tinggi untuk menghasilkan watermark yang tahan terhadap serangan. Pengujian dilakukan dengan memberikan beberapa jenis serangan. Selain itu, pada penelitian ini juga dibandingkan dua level transformasi untuk mengetahui pengaruh jumlah level transformasi terhadap imperceptibility dan robustness.

\section{Metode}

\subsection{Watermarking Citra Digital}

Watermarking citra digital merupakan proses untuk menyisipkan informasi ke dalam citra digital. Informasi yang disisipkan berupa citra yang disebut dengan watermark sedangkan citra tempat disisipkannya watermark disebut dengan citra host.

Terdapat dua proses utama di dalam watermarking citra digital, yaitu proses penyisipan (embedding) dan ekstraksi (extraction). Proses embedding merupakan proses untuk menyisipkan watermark sehingga menghasilkan citra yang nantinya diistilahkan dengan citra terwatermark. Sedangkan ekstraksi adalah proses mengembalikan watermark yang telah disisipkan ke dalam citra host.

Kriteria watermarking yang baik dapat dilihat dari tingkat imperceptibility, robustness dan capacity [4]. Kriteria impercebtibility (dapat juga diistilahkan invisibility atau fidelity) merujuk pada kesamaan antara citra host sebelum dan setelah diberi watermark. Citra yang telah diberi watermark harusnya mirip dengan citra sebelum diberi watermark sehingga tidak terdeteksi oleh sistem penglihatan manusia (Human Visual System). Dengan kata lain, citra host tidak mengalami degradasi karena adanya watermark yang disisipkan atau juga dapat dikatakan bahwa watermark tidak merusak kualitas citra host. Robustness berarti bahwa watermark harus tahan terhadap pemrosesan citra digital baik secara geometris seperti kompresi dan rotasi ataupun juga secara non-geometris seperti pemberian noise. Robustness dapat juga berarti kemampuan untuk mengembalikan watermak setelah diberi serangan. Adapun capacity adalah besar watermark yang dapat ditampung oleh host.

Watermarking citra digital diklasifikan ke dalam beberapa jenis. Berdasarkan tipe data host yang digunakan, watermarking dibedakan menjadi watermarking citra, teks, audio dan video. Berdasarkan letak penyisipan watermark terbagi dua, watermarking domain spasial dan domain transform [6]. Pada watermarking domain spasial, watermark langsung disisipkan ke dalam nilai piksel. Sehingga penerapannya lebih mudah untuk dilakukan dan dapat menghasilkan kualitas citra yang baik dengan komputasi yang rendah. Akan tetapi, teknik watermarking ini kurang tahan terhadap serangan (attacks) yang diberikan. Watermarking pada domain transform, menggunakan koefisien transformasi untuk menyisipkan watermark. Keunggulannya, watermark sangat tahan terhadap serangan. Di antara metode watermarking domain spasial yang banyak diteliti adalah Least Bit Significant (LSB) [3] dan Intermediate Significant Bit (ISB) [7]. Berbeda halnya dengan watermarking dalam domain transform, sinyal ditransformasi terlebih dahulu kemudian watermark disisipkan pada koefisien domain transformasi. Contohnya adalah metode Discrete Fourier Transform (DFT) [8], Discrete Cosine Transform (DCT) dan Discrete Wavelet Transform (DWT) [9]. Metode domain transform, menjadikan watermark tidak mudah untuk dideteksi atau dapat dikatakan lebih robust.

Beberapa penelitian yang terkait dengan watermarking di antaranya adalah yang dilakukan oleh R. Aarthi dkk [3]. R. Ararthi menyisipkan watermark pada domain spasial menggunakan Least Significant Bit (LSB) yang ketiga dan keempat untuk menyembunyikan watermark. Untuk meningkatkan impercebtibility, digunakan strategi seleksi (selection strategy) dengan menyeleksi piksel secara acak. Kualitas citra diukur dengan Peak Signal Noise Ratio (PSNR) yang menghasilkan 
ILKOM Jurnal Ilmiah Volume 11 Nomor 1 April 2019

Terakreditasi peringkat 3 SK. No. 28/E/KPT/2019

nilai tertinggi $61.64 \mathrm{~dB}$. Hanya saja, pada penelitian ini tidak memperhitungkan ketahanan terhadap pemrosesan citra digital.

Penelitian yang dilakukan oleh A. Poljicak dkk [8] yaitu watermarking menggunakan DFT. PSNR juga digunakan untuk mengevaluasi kualitas degradasi citra host. Hasil yang diperoleh digunakan untuk mengembangkan strategi watermarking dengan memilih radius optimal untuk meminimalkan degradasi. Rata rata PSNR yang dihasilkan sebesar $40 \mathrm{~dB}$. Ketahanan (robustness) juga diuji dengan pemberian beberapa serangan pada citra terwatermark. Hasil penelitian menunjukkan bahwa, skema watermarking robust terhadap serangan kompresi.

Penyisipan watermak pada domain transform juga dilakukan oleh A. Benoraira dkk [9] mencoba menggabungkan DWT dan DCT untuk watermarking pada citra keabu-abuan (grayscale). Watermark ditransformasi menggunakan DWT terlebih dahulu kemudian memanfaatkan subband frekuensi rendah untuk selanjutnya ditransformasi menggunakan DCT. Penelitian ini menghasilkan PSNR dengan nilai paling tinggi $46 \mathrm{~dB}$.

Adapun penelitian ini akan menggunakan domain transform berbasis wavelet yaitu Stationary Wavelet Transform (SWT). SWT akan diterapkan pada watermarking untuk citra berwarna. Penelitian yang dilakukan oleh N. Choubey dan M. K. Pandey [5] juga memakai SWT namun untuk citra greyscale dan watermark disisipkan pada subband dengan frekuensi rendah melalui nilai singular. Adapun pada penelitian ini, citra watermark dan host yang digunakan adalah citra berwarna (RGB) yang disisipkan pada frekuensi tinggi untuk menghasilkan watermark yang tahan (robust) terhadap serangan.

\subsection{Stationary Wavelet Transform (SWT)}

Stationary Wavelet Transform (SWT) merupakan bentuk transformasi wavelet yang dirancang untuk mengatasi kekurangan Discrete Wavelet Transform (DWT) [5]. DWT dan SWT bekerja pada gelombang kecil yang memiliki frekuensi yang berbeda. Gelombang kecil ini disebut dengan wavelet. Citra ditransformasi sebagai sinyal bergerak melalui dua filter, tapis rendah (Low Pass filter) dan tapis tinggi (High Pass Filter). Proses transformasi ini akhirnya akan menghasilkan empat subband citra, Low-Low (LL) pada frekuensi paling rendah, Low-High (LH) dan High-Low (HL) untuk bagian detail dan High-High $(\mathrm{HH})$ untuk frekuensi tinggi. Adanya empat subband yang dihasilkan membuat SWT tepat digunakan untuk mengidentifikasi area dimana watermark ingin disisipkan secara efektif. llustrasi proses transformasi DWT dan SWT sampai menghasilkan empat subband ditunjukkan pada gambar 1.

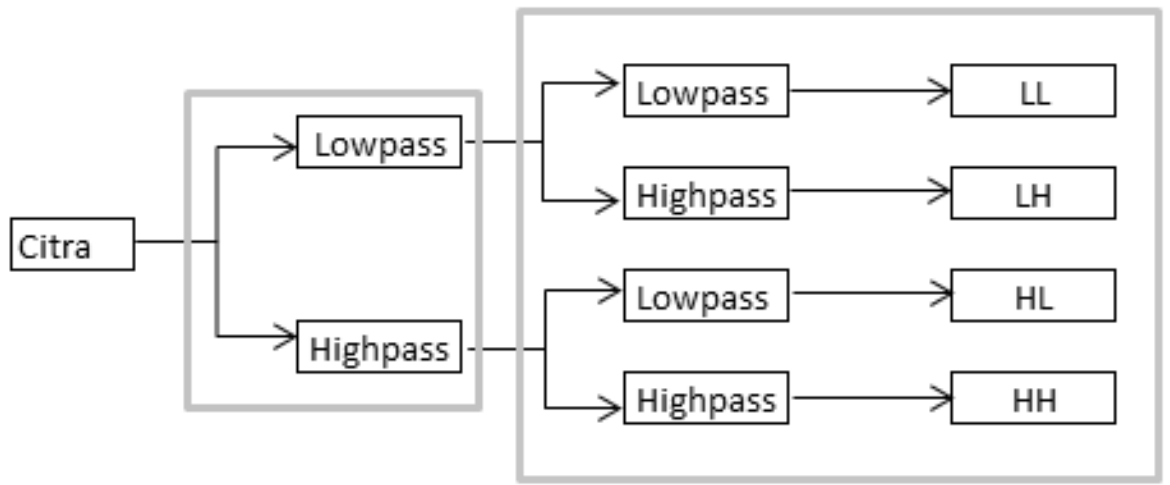

Gambar 1. Proses Transformasi SWT dan DWT

Pada DWT, setiap subband hasil transformasi berukuran seperempat kali dari citra asli sebelum ditransformasi. Subband frekuensi rendah LL menghasilkan citra yang mirip dengan citra aslinya sehingga disebut juga dengan koefisien aproksimasi. Sedangkan, $\mathrm{LH}, \mathrm{HL}$ dan $\mathrm{HH}$ merupakan koefisien detail karena menampilkan citra yang sangat halus berupa tepi citra.

Contoh hasil transformasi citra menggunakan SWT dapat dilihat pada gambar 2. Citra asli setelah dilakukan transformasi menghasilkan citra LL, LH, HL dan HH. Citra pada subband LL menghasilkan citra yang sama dengan citra asli. Sedangkan pada $\mathrm{LH}, \mathrm{HL}$ dan $\mathrm{HH}$ berupa gambar hitam yang jika diperbesar terlihat garis halus tepi objek di dalam gambar. Sifat ini dapat dimanfaatkan untuk watermarking karena penyisipan watermark pada citra yang halus tidak mempengaruhi persepsi sistem penglihatan manusia. 


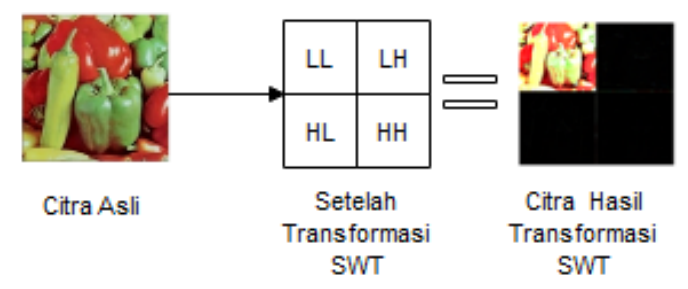

Gambar 2. Hasil Transformasi Citra Menggunakan SWT

Perbedaan SWT dan DWT adalah pada proses downsampling. Downsampling merupakan proses pergeseran invariant pada DWT yang menyebabkan penurunan nilai piksel. Hal ini juga menyebabkan ukuran citra berubah menjadi dua kali lebih kecil daripada citra asli. Akan tetapi, pada transformasi SWT tidak terjadi proses downsampling sehingga tidak terjadi pergeseran invariant. Ini mengakibatkan ukuran citra transformasi akan sama dengan ukuran citra asli. Sifat ini dimanfaatkan untuk menciptakan skema watermark yang robust karena dapat mengekstrak watermark dengan baik.

Selain tidak adanya pergeseran invarian yang terjadi, transformasi SWT dapat mereduksi noise jika diberikan serangan sehingga dapat tetap menjaga imperceptibility pada citra.

\subsection{Metode Penyisipan Watermark}

Pada penelitian ini, proses penyisipan watermark membutuhkan citra watermark dan citra host. Pada level 1 transformasi, setiap citra ditransformasi SWT sehingga diperoleh subband LL, LH, HL dan $\mathrm{HH}$ untuk masing-masing citra. Pada level 2, citra LL kemudian ditransformasi kembali sehingga menghasilkan LL2, LH2, HL2 dan HH2. Setelah itu, sisipkan watermark dan dilakukan invers SWT sehingga menghasilkan citra terwatermark. Detail proses penyisipan watermark, dituliskan secara keseluruhan sebagai berikut :

1. Baca citra watermark dan citra host

2. Lakukan transformasi SWT level 1 sehingga menghasilkan $\mathrm{LL}, \mathrm{LH}, \mathrm{HL}$ dan $\mathrm{HH}$ pada setiap citra.

3. Lakukan transformasi SWT level 2 pada subband LL sehingga menghasilkan LL2, LH2, HL2 dan $\mathrm{HH} 2$

4. Watermark disisipkan pada subband frekuensi tinggi $(\mathrm{HH})$ menggunakan rumus (1) :

$$
H H 2_{W M}=H H 2_{H}+H H 2_{w} * k
$$

Dimana :

$\begin{array}{ll}\mathrm{HH} 2_{W M} & : \text { Subband } \mathrm{HH} \text { citra terwatermark } \\ \mathrm{HH} 2_{\mathrm{H}} & \text { : Subband } \mathrm{HH} \text { citra host } \\ \mathrm{HH} 2_{W} & : \text { Subband } \mathrm{HH} \text { watermark } \\ k & : \text { Faktor skala }\end{array}$

5. Lakukan transformasi balik menggunakan Inverse SWT level 2 untuk memperoleh citra terwatermark.

\subsection{Metode Ekstraksi Watermark}

Tahap ini membutuhkan citra watermark, citra host dan citra terwatermark untuk memanggil watermark yang telah disisipkan ke dalam citra host. Pada level 1 , citra ditransformasi terlebih dahulu menggunakan SWT yang menghasilkan subband LL, LH, HL dan HH. Pada level 2, setelah itu dilanjutkan transformasi setiap citra pada level 2. Detail proses penyisipan watermark, dituliskan secara keseluruhan sebagai berikut :

1. Baca citra watermark, citra host dan citra terwatermark.

2. Lakukan transformasi SWT level 1 sehingga menghasilkan LL, LH, HL dan HH setiap citra

3. Lakukan transformasi SWT level 2 pada subband LL sehingga menghasilkan LL2, LH2, HL2 dan $\mathrm{HH} 2$

4. Watermark dikeluarkan menggunakan rumus berikut :

$$
H H 2_{W}=\frac{\left(H H 2_{W M}-H H 2_{H}\right)}{k}
$$


ILKOM Jurnal Ilmiah Volume 11 Nomor 1 April 2019

Terakreditasi peringkat 3 SK. No. 28/E/KPT/2019

$\begin{array}{ll}\text { Dimana : } & \\ H H 2_{W M} & : \text { Subband } \mathrm{HH} \text { citra terwatermark } \\ H H 2_{H} & : \text { Subband } \mathrm{HH} \text { citra host } \\ H H 2_{W} & : \text { Subband } \mathrm{HH} \text { watermark } \\ k & \text { : Faktor skala }\end{array}$

5. Lakukan transformasi balik menggunakan Inverse SWT level 2 untuk memperoleh citra terwatermark.

\section{Hasil dan Pembahasan}

Untuk mengimplementasikan skema watermarking menggunakan SWT ini, digunakan empat citra warna berukuran 512 × 512 piksel sebagai host, yaitu citra baboon.bmp, peppers.jpg, lichtenstein.png dan sailboat.bmp serta satu citra watermark berwarna, yaitu umicopy.bmp. Gambar yang dipakai ditunjukkan pada gambar 3.

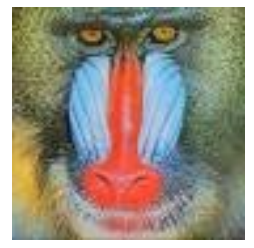

Baboon.bmp

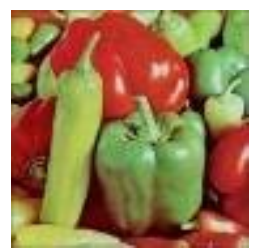

Peppers.bmp

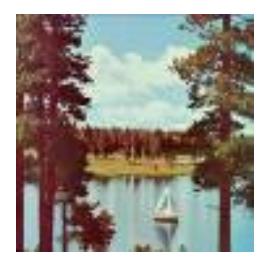

Sailboat.bmp
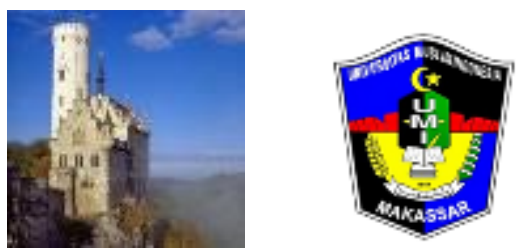

Lichtenstein.png Umicopy.bmp

Gambar 3. Hasil Transformasi Citra Menggunakan SWT

Setelah melakukan penyisipan watermark pada citra host dan diperoleh citra terwatermark, dilakukan dua jenis pengujian yaitu pengujian imperceptibilty dan robustness. Sebagai tambahan, pada penelitian ini juga dibandingkan dua level transformasi SWT untuk mengetahui pengaruh jumlah level transformasi terhadap imperceptibility dan robustness.

\subsection{Pengujian Tingkat Imperceptibility}

Watermark yang disisipkan seharusnya tidak merusak kualitas citra host. Untuk mengetahui bagaimana pengaruh penyisipan watermark terhadap kualitas citra host, dilakukanlah pengujian imperceptibility menggunakan Peak Signal Noise Ratio (PSNR) dan Mean Square Error (MSE). Rumus yang dipakai untuk menghitung MSE dan PSNR pada citra berukuran $M \times N$ adalah rumus (3)

$$
M S E=\frac{1}{M N} \sum_{x=1}^{M} \sum_{y=1}^{N}[H(x, y)-W M(x, y)]^{2}
$$

Dimana :

$W M(x, y) \quad$ : Nilai intensitas citra terwatermark pada kordinat $(\mathrm{x}, \mathrm{y})$

$H(x, y) \quad$ : Nilai intensitas citra host pada kordinat $(\mathrm{x}, \mathrm{y})$

$$
P S N R=20 \log _{10} \frac{(255)}{\sqrt{M S E}}
$$

PSNR dinyatakan dalam skala logaritmik dengan desibel (dB) untuk mengevaluasi kesamaan antara citra host dan citra terwatermark. Semakin tinggi nilai PSNR, berarti semakin baik kualitas citra terwatermark. Nilai PSNR yang berada di bawah $30 \mathrm{~dB}$ menunjukkan kualitas citra yang buruk dan tidak dapat diterima. Citra yang berkualitas baik haruslah di atas 40dB [10]. Berbeda dengan MSE, nilai yang diharapkan adalah MSE yang kecil karena menunjukkan distorsi atau error yang terjadi. Rumus (4) menunjukkan bahwa nilai MSE berbanding terbalik dengan PSNR. Semakin kecil nilai MSE, maka semakin tinggi pula nilai PSNR. 
ILKOM Jurnal Ilmiah Volume 11 Nomor 1 April 2019

Terakreditasi peringkat 3 SK. No. 28/E/KPT/2019

Adapun nilai MSE dan PSNR hasil pengujian untuk empat citra host ditunjukkan pada tabel 1 dan 2 berikut :

Tabel 1. Hasil Pengujian Imperceptibility Menggunakan MSE

Nilai MSE Citra Terwatermark

Di setiap Channel Warna RGB

\begin{tabular}{ccccccc}
\multirow{2}{*}{ Nama Citra } & \multicolumn{2}{c}{$\begin{array}{c}\text { Di setiap Channel Warna RGB } \\
\text { (Level 1) }\end{array}$} & \multicolumn{2}{c}{$\begin{array}{c}\text { Di setiap Channel Warna RGB } \\
\text { (Level 2) }\end{array}$} \\
\cline { 2 - 7 } & $\begin{array}{c}\text { Channel } \\
\text { Red }(R)\end{array}$ & $\begin{array}{c}\text { Channel } \\
\text { Green }(G)\end{array}$ & $\begin{array}{c}\text { Channel } \\
\text { Blue }(B)\end{array}$ & $\begin{array}{c}\text { Channel } \\
\text { Red (R) }\end{array}$ & $\begin{array}{c}\text { Channel } \\
\text { Green }(G)\end{array}$ & $\begin{array}{c}\text { Channel } \\
\text { Blue (B) }\end{array}$ \\
\hline Baboon.bmp & 0.0017 & 0.0017 & 0.0048 & 4.982 & 4.871 & 4.272 \\
Peppers.bmp & 0.0017 & 0.0016 & 0.0047 & 0.161 & 0.157 & 0.176 \\
Lichtenstein.png & 0.0017 & 0.0017 & 0.0048 & 0.557 & 0.581 & 0.560 \\
Sailboat.bmp & 0.0017 & 0.0017 & 0.0048 & 2.008 & 3.005 & 1.785 \\
\hline
\end{tabular}

Tabel 2. Hasil Pengujian Imperceptibilty Menggunakan Nilai PSNR

\begin{tabular}{|c|c|c|c|c|c|c|}
\hline \multirow[t]{2}{*}{ Nama Citra } & \multicolumn{3}{|c|}{$\begin{array}{c}\text { Nilai PSNR Citra Terwatermark } \\
\text { Di setiap Channel Warna RGB } \\
\text { (Level 1) }\end{array}$} & \multicolumn{3}{|c|}{$\begin{array}{c}\text { Nilai PSNR Citra Terwatermark } \\
\text { Di setiap Channel Warna RGB } \\
\text { (Level 2) }\end{array}$} \\
\hline & $\begin{array}{l}\text { Channel } \\
\text { Red (R) }\end{array}$ & $\begin{array}{l}\text { Channel } \\
\text { Green (G) }\end{array}$ & $\begin{array}{l}\text { Channel } \\
\text { Blue (B) }\end{array}$ & $\begin{array}{l}\text { Channel } \\
\text { Red (R) }\end{array}$ & $\begin{array}{l}\text { Channel } \\
\text { Green (G) }\end{array}$ & $\begin{array}{l}\text { Channel } \\
\text { Blue (B) }\end{array}$ \\
\hline Baboon.bmp & 75.7744 & 75.8034 & 71.3575 & 41.190 & 41.288 & 41.858 \\
\hline Peppers.bmp & 75.7744 & 76.0941 & 71.4136 & 56.086 & 57.950 & 55.706 \\
\hline Lichtenstein.png & 75.7744 & 75.8034 & 71.3575 & 50.705 & 50.521 & 50.678 \\
\hline Sailboat.bmp & 75.7744 & 75.8131 & 71.3575 & 45.137 & 43.385 & 45.647 \\
\hline
\end{tabular}

Pada tabel 2 dapat dilihat bahwa penyisipan watermark pada level 1 menghasilkan nilai MSE menghampiri 0 yang berarti nilai intensitas distorsi setelah diberi watermark sangat kecil. Hal ini juga mempengaruhi nilai PSNR yang dihasilkan. Error yang paling kecil adalah 0.0016 pada citra Peppers di channel Green, membuat nilai PSNRnya juga paling besar, yaitu $76.0941 \mathrm{~dB}$. Sebaliknya, error yang besar yaitu 0.0048 yang membuat nilai PSNR juga paling kecil yaitu 71.3575. Akan tetapi secara keseluruhan, pada level 1 menghasilkan nilai PSNR di atas $70 \mathrm{~dB}$. Ini menunjukkan nilai PSNR yang dihasilkan sangat tinggi.

Berbeda nilainya jika watermark disisipkan pada level 2. Nilai MSE yang paling rendah 0.161 dan paling tinggi 4.982. PSNR yang dihasilkan paling tinggi $57.950 \mathrm{~dB}$ pada citra Peppers dan paling rendah 41.190 pada citra Baboon di channel Red. Hasil pengujian menunjukkan bahwa nilai PSNR level 1 lebih tinggi dibandingkan level 2 dan nilai MSE lebih kecil dibanding level 2. Hal ini disebabkan oleh adanya distorsi saat transformasi. Sehingga karena pada level 2 terjadi transformasi sebanyak 2 kali, yang menyebabkan informasi yang hilang lebih banyak daripada level 1. Akan tetapi, secara keseluruhan, nilai yang diperoleh merupakan nilai PSNR yang tinggi karena berada di atas $40 \mathrm{~dB}$. Ini berarti kualitas citra setelah diberi watermark sangat baik.

Tabel 3. Hasil Penyisipan Watermark ke Citra Host

\begin{tabular}{|c|c|c|c|}
\hline \multirow{2}{*}{ Nama Citra } & \multirow{2}{*}{ Citra Asli } & \multicolumn{2}{|c|}{ Citra Terwatermark } \\
\hline & & Level 1 & Level 2 \\
\hline Baboon.bmp & & & \\
\hline Peppers.bmp & & & \\
\hline
\end{tabular}


ILKOM Jurnal Ilmiah Volume 11 Nomor 1 April 2019

Terakreditasi peringkat 3 SK. No. 28/E/KPT/2019

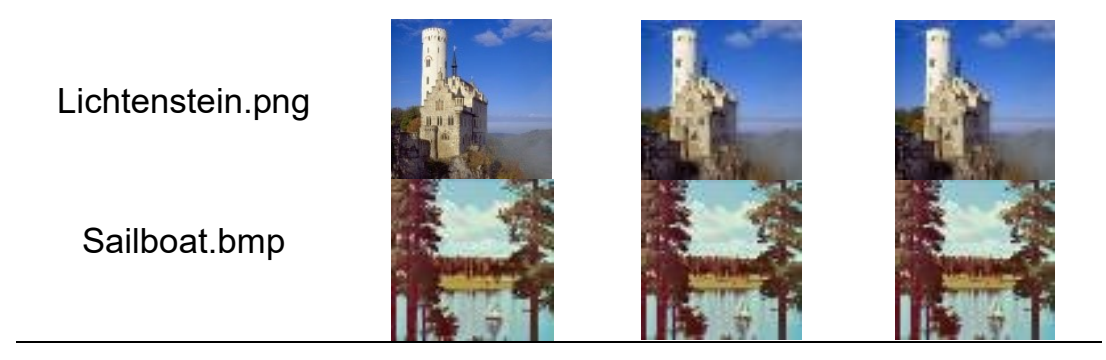

Hasil yang ditunjukkan pada tabel 3 merupakan citra host setelah disisipkan watermark di dalamnya. Citra terwatermark yang dihasilkan secara visual mirip dengan citra host baik pada level 1 dan 2. Selain itu, tidak tampak adanya watermark yang disisipkan (invisible). Ini berarti watermark yang disisipkan tersimpan dengan baik dan tidak merusak kualitas citra host. Nilai PSNR tinggi yang diperoleh tadi juga dapat membuktikan bahwa metode dalam penelitian ini memiliki tingkat imperceptibilty yang baik.

\subsection{Pengujian Tingkat Robustness}

Pengujian robustness bertujuan untuk mengetahui tingkat ketahanan watermark jika diberikan beberapa serangan berupa pemrosesan citra digital. Ketahanannya dapat dilihat dari seberapa besar watermark dapat dipanggil kembali saat ekstraksi. Untuk menilai hal tersebut, dilakukan perhitungan menggunakan rumus (3) Normalized Correction (NC), yaitu :

$$
N C=\frac{\sum_{x=1}^{M} \sum_{y=1}^{N} \sum_{z=1}^{O}\left[W(x, y, z) W^{\prime}(x, y, z)\right]}{\sqrt{\sum_{x=1}^{M} \sum_{y=1}^{N} \sum_{z=1}^{O}[W(x, y, z)]^{2}} \sqrt{\sum_{x=1}^{M} \sum_{y=1}^{N} \sum_{z=1}^{O}\left[W^{\prime}(x, y, z)\right]^{2}}}
$$

Dimana :

$W(x, y, z) \quad$ : Nilai intensitas citra watermark asli pada kordinat $(\mathrm{x}, \mathrm{y}, \mathrm{z})$

$W^{\prime}(x, y, z) \quad$ : Nilai intensitas citra watermark setelah diberi serangan pada kordinat $(\mathrm{x}, \mathrm{y}, \mathrm{z})$

$M, N$ dan $O$ : dimensi citra watermark asli

Nilai NC diperoleh dengan mengekstrak watermark dari citra terwatermark. NC menunjukkan tingkat kemiripan watermark sebelum dan setelah diberi serangan. Dapat juga disebut sebagai tingkat ekstraksi watermark. Semakin besar nilai NC, semakin mirip watermark asli dan watermark setelah diberi serangan. Nilai NC berada di antara 0 dan 1 . Nilai 0 berarti watermark setelah diberi serangan, tidak ada kemiripan sama sekali dengan watermark asli. Sebaliknya, yang bernilai 1 berarti kedua citra yang dibandingkan sama persis.

Pada pengujian robustness ini, citra terwatermark diberikan beberapa serangan sebelumnya. Serangan yang diberikan berupa pemrosesan citra digital seperti Salt and Pepper Noise, Speckle Noise, Gaussian, Blur, kompresi dan rotasi. Setelah itu, citra diekstraksi dan dibandingkan antara watermark hasil ekstraksi dan watermark asli kemudian dihitung nilai NC.

Tahap awal, dilakukan perhitungan nilai NC sebelum citra terwatermark diberi serangan. Ini bertujuan untuk mengetahui kemampuan skema watermarking dapat mengembalikan seperti aslinya tanpa adanya serangan. Nilai yang diberikan dimasukkan ke dalam tabel 4 :

Tabel 4. Hasil Penyisipan Watermark ke Citra Host

\begin{tabular}{ccc}
\hline Nama Citra & $\begin{array}{c}\text { Nilai NC Citra Terwatermark } \\
\text { Sebelum diberi serangan } \\
\text { (Level 1) }\end{array}$ & $\begin{array}{c}\text { Nilai NC Citra Terwatermark } \\
\text { Sebelum diberi serangan } \\
\text { (Level 2) }\end{array}$ \\
\hline Baboon.bmp & 0.9999 & 0.9930 \\
Peppers.bmp & 0.9999 & 0.9993 \\
Lichtenstein.png & 0.9999 & 0.9972 \\
Sailboat.bmp & 0.9999 & 0.9971 \\
\hline
\end{tabular}


ILKOM Jurnal Ilmiah Volume 11 Nomor 1 April 2019

Terakreditasi peringkat 3 SK. No. 28/E/KPT/2019

Tabel 4 menunjukkan tingkat pengembalian watermark pada level 1 dan level 2 SWT. Pada tabel, Nilai NC level 1 lebih besar di bandingkan pada level 2. Ini berarti bahwa ekstraksi watermark lebih baik di level 1 dibandingkan di level 2 jika belum diberikan serangan. Hal ini karena jumlah transformasi pada level 2 mengakibatkan adanya distorsi yang lebih besar dibandingkan pada level 1. Rata-rata kemiripan watermark asli dan hasil ekstraksi pada level 1 sebesar 0.9999. Sedangkan, pada level 2, nilai tertinggi sebesar 0.9993 dan paling rendah 0.9971 . Nilai ini menunjukkan nilai pengembalian watermark yang sangat baik. Ini juga yang menyebabkan watermark ekstraksi dengan watermark asli sangat mirip.

Tahapan selanjutnya adalah memberikan serangan pada citra terwatermark kemudian mengekstrak watermarknya untuk selanjutnya dihitung nilai NC. Adapun nilai NC yang dihasilkan dalam pengujian ini terhadap beberapa serangan ditampilkan pada tabel berikut:

Tabel 5. Hasil Pengujian Robustness Level 1 Menggunakan NC

\begin{tabular}{ccccc}
\hline \multirow{2}{*}{ Jenis serangan } & \multicolumn{3}{c}{ Nilai Normalized Correction (NC) Pada Level 1 } \\
\cline { 2 - 4 } & Baboon & Peppers & Lichtenstein & Sailboat \\
\hline $\begin{array}{c}\text { Salt and Pepper } \\
\text { (dense 0.01) }\end{array}$ & 0.9838 & 0.9822 & 0.9829 & 0.9831 \\
$\begin{array}{c}\text { Salt and Pepper } \\
\text { (dense 0.05) }\end{array}$ & 0.9508 & 0.9466 & 0.9492 & 0.9474 \\
Speckle (density & 0.9665 & 0.9685 & 0.9664 & 0.9678 \\
0.01) & & & & \\
Speckle (density & 0.9541 & 0.9541 & 0.9542 & 0.9531 \\
0.05) & 0.9597 & 0.9601 & 0.9599 & 0.9600 \\
Gaussian Noise & 0.9723 & 0.9993 & 0.9890 & 0.9738 \\
Blurring & 0.9669 & 0.9906 & 0.9850 & 0.9701 \\
Rotasi degree15 & 0.9642 & 0.9906 & 0.9784 & 0.9672 \\
Rotasi degree 90 & 0.9700 & 0.9977 & 0.9865 & 0.9722 \\
Kompresi (Q=80) & 0.9695 & 0.9938 & 0.9865 & 0.9721 \\
Kompresi (Q=30) & & & & \\
\hline
\end{tabular}

Dari tabel 5, kita dapat mengetahui bahwa nilai yang paling rendah untuk setiap citra ketika diberi serangan Salt and Pepper dengan konstanta 0.05. Kemudian diikuti oleh serangan Speckle konstanta 0.05 yang memberikan nilai rata rata 0.9541 . Pemberian konstanta noise yang besar menjadikan nilai NC juga berkurang. Nilai terbaik yaitu ketika diberi serangan Blur pada peppers dan Lichtenstein serta serangan Salt and Pepper (0.01) pada Baboon dan Sailboat. Secara keseluruhan, nilai NC yang diperoleh yaitu berada di atas 0.9466. Ini memberi arti bahwa hasil ekstraksi semakin mirip dengan watermark asli. Dengan kata lain, pada level 1 semua watermark dapat diekstrak dengan baik meskipun diberi serangan.

Tabel 6. Hasil Pengujian Robustness Level 2 Menggunakan NC

\begin{tabular}{ccccc}
\hline \multirow{2}{*}{ Jenis serangan } & \multicolumn{3}{c}{ Nilai Normalized Correction (NC) Pada Level 2 } \\
\cline { 2 - 5 } & Baboon & Peppers & Lichtenstein & Sailboat \\
\hline $\begin{array}{c}\text { Salt and Pepper } \\
\text { (dense 0.01) }\end{array}$ & 0.9843 & 0.9884 & 0.9868 & 0.9870 \\
$\begin{array}{c}\text { Salt and Pepper } \\
\text { (dense 0.05) }\end{array}$ & 0.9714 & 0.9722 & 0.9720 & 0.9721 \\
$\begin{array}{c}\text { Speckle (dense } \\
\text { 0.01) }\end{array}$ & 0.9799 & 0.9843 & 0.9819 & 0.9804 \\
Speckle (dense & 0.9719 & 0.9752 & 0.9725 & 0.9728 \\
0.05) & 0.9732 & 0.9728 & 0.9733 & 0.9731 \\
Gaussian Noise & 0.9899 & 0.9993 & 0.9972 & 0.9971 \\
Blurring & 0.9797 & 0.9953 & 0.9899 & 0.9878 \\
Rotasi 15 & 0.9785 & 0.9953 & 0.9872 & 0.9859 \\
Rotasi 90 & 0.9995 & 0.9995 & 0.9952 & 0.9935 \\
Kompresi (Q=80) & 0.9849 & 0.9973 & 0.9931 & 0.9921 \\
\hline Kompresi (Q=30) & & & & \\
\hline
\end{tabular}


ILKOM Jurnal Ilmiah Volume 11 Nomor 1 April 2019

Terakreditasi peringkat 3 SK. No. 28/E/KPT/2019

Sama halnya dengan pengujian level 2 , seperti ditunjukkan pada tabel 6 , nilai NC yang paling rendah saat diberi serangan Salt and Pepper 0.05 untuk setiap citra. Dapat dikatakan, watermark kurang tahan terhadap noise Salt and Pepper 0.05 dibandingkan serangan lain. Nilai ekstraksi terbesar pada kompresi $Q=80$ untuk Baboon dan Peppers sebesar 0.9995, serta Blurring pada Lichtenstein dan Sailboat sebesar 0.9972 dan 0.9971. Secara keseluruhan, pengujian menghasilkan nilai ekstraksi yang sangat baik, yaitu di atas 0.97. Ini berarti watermark yang disisipkan kuat (robust) terhadap serangan yang diberikan.

Untuk pengujian terhadap beberapa serangan pemrosesan citra, jika dibandingkan dengan nilai level 1, nilai NC pada level 2 lebih tinggi. Berbanding terbalik dengan nilai PSNR, dimana nilai PSNR level 1 lebih besar dibanding level 2.

Tabel 7. Hasil Ekstraksi Watermark Setelah Diberi Serangan (Citra Baboon)

\begin{tabular}{|c|c|c|c|c|c|}
\hline \multirow{2}{*}{ Jenis serangan } & \multicolumn{2}{|c|}{ Hasil Ekstraksi } & \multirow{2}{*}{$\begin{array}{c}\text { Jenis } \\
\text { serangan }\end{array}$} & \multicolumn{2}{|c|}{ Hasil Ekstraksi } \\
\hline & Level 1 & Level 2 & & Level 1 & Level 2 \\
\hline Tanpa Serangan & & & Rlurring & & \\
\hline $\begin{array}{l}\text { Salt and Pepper } \\
\quad \text { (dense 0.01) }\end{array}$ & & & Rotasi 15 & & \\
\hline $\begin{array}{l}\text { Salt and Pepper } \\
\text { (dense 0.05) }\end{array}$ & & & Rotasi 90 & & \\
\hline $\begin{array}{c}\text { Speckle (dense } \\
0.01)\end{array}$ & & & $\begin{array}{l}\text { Kompresi } \\
(Q=80)\end{array}$ & & \\
\hline $\begin{array}{c}\text { Speckle (dense } \\
0.05)\end{array}$ & & & $\begin{array}{l}\text { Kompresi } \\
(Q=30)\end{array}$ & & \\
\hline Gaussian Noise & & & & & \\
\hline
\end{tabular}

Tabel 7 merupakan hasil ekstraksi watermark setelah diberikan beberapa serangan. Secara visual, watermark ekstraksi sangat dapat dikenali karena mirip dengan watermark asli. Ini juga dapat dikatakan bahwa watermark stabil terhadap serangan yang diberikan.

Setiap pengujian yang dilakukan, dapat memperoleh nilai PSNR dan NC yang sangat tinggi baik pada level 1 maupun pada level 2 . Hal ini disebabkan oleh tidak adanya pergeseran invariant saat terjadi downsampling transformasi SWT. Sehingga posisi watermark pada host juga tidak mengalami pergeseran. Dengan kata lain, watermak dapat terekstrak dengan baik sebelum atau 
sesudah diberi serangan (robust). Selain itu, watermark yang disisipkan tidak mengganggu atau merusak kualitas citra host.

Oleh karena itu, keseluruhan pengujian yang dilakukan, ini menunjukkan bahwa, metode watermarking menggunakan Stationary Wavelet Transform yang diteliti, memiliki tingkat imperceptibility dan robustness yang baik.

\section{Kesimpulan dan Saran}

Berdasarkan pengujian yang dilakukan pada penelitian ini dengan judul "Watermarking Citra Digital Berwarna Menggunakan Stationary Wavelet Transform (SWT)" dapat disimpulkan bahwa :

1. Dari segi imperceptibility, metode yang digunakan menghasilkan nilai PSNR yang sangat tinggi yaitu pada level 2 diperoleh nilai di atas $40 \mathrm{~dB}$ untuk keseluruhan citra, dengan nilai tertinggi sebesar $57.950 \mathrm{~dB}$. Bahkan jika penyisipan dilakukan pada level 1, dapat menghasilkan PSNR di atas $70 \mathrm{~dB}$. Ini menunjukkan bahwa metode yang digunakan memiliki tingkat imperceptibility yang baik.

2. Dari segi robustness, tingkat kemiripan citra watermark ekstraksi dengan watermark asal pada level 1 dan 2 sangat tinggi. Untuk setiap citra, Nilai NC paling rendah pada level 1 dan 2 ketika diberi serangan Salt and Pepper 0.05. Nilai paling tinggi pada level 1, yaitu jika diberi serangan Blurring pada citra Peppers dan Lichtenstein serta serangan Salt and Pepper 0.01 untuk citra Sailboat dan Baboon. Pada level 1, nilai NC mulai dari 0.9466 sampai nilai 0.9993 sedangkan pada level 2, mulai dari 0.9714 sampai 0.9995 . Ini merupakan nilai yang sangat tinggi dan menunjukkan bahwa metode dalam penelitian ini memiliki tingkat robustness yang sangat baik.

3. Berdasarkan data yang diperoleh, dari segi imperceptibility, nilai PSNR pada level 1 lebih baik dibandingkan pada level 2. Dari segi robustness, level 2 lebih baik daripada level 1.

\section{Daftar Pustaka}

[1] C. Lin, C. Chang, and Y. Chen, "A Novel SVD-based Watermarking Scheme for," J. Inf. Hiding Multimed. Signal Process. Ubiquitous Int., vol. 5, no. 2, pp. 124-143, 2014.

[2] A. Pareek and P. Sinha, "Image Data Authentication using Watermarking Scheme by DWT based Data Embedding Approach," I. Engineering pp. 9497-9505, 2015.

[3] R. AARTHI, V. JAGANYA, and S. POONKUNTRAN, "Modified LSB Watermarking for Image Authentication," Int. J. Comput. ..., pp. 62-65, 2012.

[4] Z. Shokrollahi and M. Yazdi, "A robust blind watermarking scheme based on stationary wavelet transform," J. Inf. Hiding Multimed. Signal Process., vol. 8, no. 3, pp. 676-687, 2017.

[5] N. Choubey and M. K. Pandey, "A Robust Watermarking Technique for Compressed Digital Image based on Stationary Wavelet Transform and Singular Value Decomposition," pp. 384389, 2015.

[6] M. Abdullatif, A. M. Zeki, J. Chebil, and T. S. Gunawan, "Properties of digital image watermarking," Proc. - 2013 IEEE 9th Int. Colloq. Signal Process. its Appl. CSPA 2013, pp. 235-240, 2013.

[7] G. N. M. -, A. Y. -, and A. M. Z. -, "High Watermarking Image Quality Based on Dual Intermediate Significant Bit (DISB)," Int. J. Digit. Content Technol. its Appl., vol. 7, no. 5, pp. 733-742, 2013.

[8] A. Poljicak, "Discrete Fourier transform-based watermarking method with an optimal implementation radius," J. Electron. Imaging, vol. 20, no. 3, p. 033008, 2011.

[9] A. Benoraira, K. Benmahammed, and N. Boucenna, "Blind image watermarking technique based on differential embedding in DWT and DCT domains," EURASIP J. Adv. Signal Process., vol. 2015, no. 1, 2015.

[10] A. Cheddad, J. Condell, K. Curran, and P. Mc Kevitt, "Digital image steganography: Survey and analysis of current methods," Signal Processing, vol. 90, no. 3, pp. 727-752, 2010. 